\title{
Faded Red Paradise: Welfare and the Soviet city after $1953^{1}$
}

Name, address and affiliation: Mark B. Smith; mbs39@cam.ac.uk; Faculty of History, West Road, University of Cambridge, CB3 9EF.

Length of article: 9,722 words incl. footnotes, excl. apparatus on p. 1.

Short description: The provision of social welfare and the shape of the Soviet city profoundly influenced each other, especially in the post-Stalin period. This article explores the relationship between welfare and city in the USSR after 1953 by focusing on four particular urban or exurban spaces: the company town, the microdistrict, the pensions office, and the city's rural hinterland. After the ideological visions of the Khrushchev era faded, welfare moved even closer to the heart of Soviet urban life. It determined some of the contours of urban form, while the resulting urban spaces contributed fundamentally to the way that people understood Soviet power and the nature of their citizenship.

Short title: Faded Red Paradise.

Short description of work in progress and previously published material: Mark B. Smith is the author of Property of Communists: The Urban Housing Program from Stalin to Khrushchev (Northern Illinois University Press, 2010). He has researched widely on the history of the 'welfare state' in the Soviet Union. Beyond housing and welfare, he has published articles and book chapters on other aspects of the Soviet experience: elections, human rights, the cultural Cold War, and the working class. He is the author of the blog Beyond the Kremlin. 


\section{Faded Red Paradise:}

\section{Welfare and the Soviet City after 1953}

What was the socialist city? Looked at from one angle, urban space took on a characteristic form in the Eastern bloc between the 1950s and 1980s. You know it when you see it: swathes of identical housing blocks; windswept concrete squares; statues of Lenin; banners eulogising workers; colourless shops without goods; grey crowds; a multiplicity of men in uniform. ${ }^{2}$ Architects and planners, first in the USSR and then across the Eastern bloc, had been committed to the idea and practice of the socialist city since the Russian Revolution. This urban form was ultimately about three things: striking, self-conscious modernity; the celebration and improvement of working-class life; and the construction in physical form of socialist ideology. Welfare was at the centre of this vision. As such, the socialist city existed in fundamental contrast to the capitalist city, which was shaped by the interests of private property, and the Nazi city, its other modern European comparator, whose ultimate driver was the violent assertion of racial purity. The city was at the heart of the socialist experiment, which was fundamentally an urban project.

As ideological enthusiasm waned, the socialist city would fail to reach its utopian potential and would in time become merely a faded red paradise. As paradise was falling out of view, during the 1970s, sociologists and urban geographers in Western universities imported the Eastern bloc notion of the 'socialist city' into mainstream Sovietology. ${ }^{3}$ According to their analysis, ideology generated common traits in cities from Varnu to Vladivostok, including the absence of ghettos and very poor areas; the removal of class conflict as a factor in shaping the appearance of cities; low 
crime; highly socialised public services; small numbers of cars; and public space designed around the needs of ritual and celebration. Planning was the key to everything. The presumed existence of the socialist city is fundamental to a growing historical literature of conceptual richness and empirical depth. ${ }^{4}$ This article seeks to follow this example, but to focus on a period whose urban history has received less attention: the years after Stalin.

But did the socialist city really exist? Cities on either side of the Iron Curtain were actually rather similar. The basic features that all modern cities had in common -- roads, apartment houses, offices -- were arguably at least as important as any ideological differences that divided them. For some observers, urbanisation and industrialisation were universal processes and produced similar results, born of comparable technology, bureaucracy and economic development. If all recent history is urban history, as Leif Jerram contends, ${ }^{5}$ then the socialist city was simply one variant of a universal form, different from Western cities only in degree, more backward perhaps, short on neon, but still the location of a way of life whose urban modernity was in its basic fundamentals the same as in the West.

What is more, historians have shown that the core feature of the socialist city -- socialist planning -- was a compromised concept. No one could doubt that planning was a major force in Soviet life, not least in terms of city design and welfare provision. But the central bureaucracy could never remotely coordinate and predict all economic activity. Local city planning was the result not of Olympian professional logic, but of intra-bureaucratic struggles and technical doubts. It was modulated by popular pressures, stubborn city identities, and the persistence of urban chaos. The state relied on citizens to exercise their individual initiative to get things done. One might wonder what was socialist about all this. 
Other historians, meanwhile, remind us that every city in the Eastern bloc, not least in the Soviet Union, was unique, possessing singular qualities rather than the generalised ones of the socialist city. L'vov (L'viv), on the post-1945 western Ukrainian borderlands, was a contested ethnic space in the imagination of many residents, and so resists easy categorisation as a socialist city. ${ }^{6}$ For sure, some cities, such as Tol'iatti, were entirely new, built out of nothing, ${ }^{7}$ but most cities were the product of a dialogue with the past. ${ }^{8}$ Cities had historic zones, especially in the centre. Here, neighbourhoods could not be reduced to tidy district units with defined socialist uses. Instead, the functions of particular buildings and pockets of territory had evolved over time rather than been suddenly transformed. One end of a street could retain a certain cachet, the other end a certain notoriety. Such micro-environments remained fundamental to how people experienced urban space in ways that seem, on balance, scarcely socialist.

But these various forces did not squeeze out the socialism from the socialist city. ${ }^{9}$ Instead, they contributed to the creation and development of an urban form that was highly distinctive, but far from an ideal type, one whose distinctiveness was further sharpened by transnational exchanges between construction professionals within the socialist bloc. ${ }^{10}$ Focusing on the USSR, and not seeking to generalise about the region as a whole, this article explores one of the most important aspects of the socialist city: its welfare system.

In the Soviet Union, welfare was in the first instance an urban phenomenon, a shaper of socialist urban modernity. The city was the principal location of welfare infrastructure and its dwellers were legally privileged recipients of its services, possessing social rights which rural citizens lacked, and which the internal passport and propiska (i.e. legal residence stamp) reinforced. ${ }^{11}$ It was only in a major welfare reform of 1964 that the pensions system was properly extended to collective farms, partly resolving a decades-long conflict between city and countryside 
(it was only a half-decade earlier that the USSR had become a majority urban society). Using welfare to privilege cities contrasted with the experience of some democracies, which actively worked to redistribute incomes from urban to rural areas, partly under the pressures of sectional interests. This was true in Sweden, for example, at least until the 1950s. ${ }^{12}$

The argument relies on four overlapping scholarly approaches. Drawing on two of the most distinguished works of Soviet urban history of the last twenty years, it follows Stephen Kotkin in imagining the Soviet city as a distinctive socialist community, ${ }^{13}$ and Karl Schlögel in attempting to demonstrate the significance of particular urban spaces in making a socialist way of life. ${ }^{14}$ It is influenced too by the 'spatial turn' in Russian studies, in which physical space -- from the street to the province to the cosmos -- is deployed as the principal factor in explaining historical change in Russian culture, society and politics. ${ }^{15}$ Most recently, the groundbreaking work on migration within the Soviet Union by Lewis H. Siegelbaum and Leslie Page Moloch reminds us that ideologically defined geographical parameters shaped the late socialist way of life. ${ }^{16}$ The article is also inspired by two decades of research by social and cultural historians on the kaleidoscope of post-1945 urbanity and everyday life, from Stephen V. Bittner on Moscow's Arbat, to Christopher J. Ward on the workers' settlements of the Baikal-Amur railway line, to Brian LaPierre on city 'hooligans' ${ }^{17}$ And it draws too on an older planning literature from the 1970s and 1980s, more top-down in perspective, to explain some of the routine connections between the welfare system and the Soviet city. ${ }^{18}$

Synthesising these secondary sources with contemporary Soviet publications, such as the professional journals of architects and social security staff, and archival documents, especially from the Ministry of Social Welfare of the USSR's Russian Republic (RSFSR) and the welfare departments of the city of Moscow, the article combines the perspectives of urban and welfare 
planners with those of ordinary people, in order to explore how welfare formed the socialist city and how the socialist city shaped welfare in four locations: the 'company town'; the 'microdistricts', post-Stalin neighbourhood units designed with welfare very much in mind; the interior urban spaces where welfare was dispensed, notably the pensions office; and the urban borderlands, where city gave way to exurbia and to the vast Soviet countryside. The aim is to demonstrate how these spaces, indoors and outdoors alike, were crucial sites of a unique 'Soviet civilisation' that was characterised by a ubiquitous, penetrating, but unevenly effective welfare system.

II

\section{Company town}

The post-Stalin company town was a legacy of Stalinism. ${ }^{19}$ It was a maxim of the Stalin era that welfare should serve industry. Urban space must facilitate this relationship. Workers gained welfare rights (which under Stalin were entirely theoretical) as a result of their employment. Their employer dispensed many of the welfare benefits to which they were entitled. Industrial enterprises owned not just factories, but apartment blocks, theatres, workers' clubs, hospitals, and schools. ${ }^{20}$ In short, the company town was an urban environment in which work, domesticity, social services and leisure were precisely connected under the auspices of an all-embracing welfare system. Company towns ranged from whole cities of little more than a single employer, such as Magnitogorsk, with its gargantuan steel works in the Urals; or a metropolitan district, such as the area around the Sickle and Hammer industrial complex in Moscow; or the small-scale, so-called workers' settlements that existed across the USSR, built around, say, a timber combine or a railway junction.

The Soviet Union was scarcely the only country to develop company towns. They had been a significant part of the urban landscape of the United States, East Asia and Western Europe, not to 
mention imperial Russia. So how was the Soviet company town different? ${ }^{21}$ Most distinctive of all, in terms of international comparison, were the large-scale urban settlements that grew up on the permeable edge of prison camps, forming one of the Stalin age's extraordinary meeting points of welfare and violence. ${ }^{22}$ More generally, beyond the Gulag complex, the Soviet company town was different from comparators in the West in four main ways: architecture and planning; the budget; the imprint of ideology; and the practice of equality.

The architecture of the company town expressed a Soviet ideological conviction. From the early 1950s, standardisation was required, but it was Soviet-style standardisation. 'Architects must [...] make wide use not only of standardised constructions and parts, but of standardised buildings and structures', decreed a December 1952 conference of architects who worked on company town assignments. ${ }^{23}$ Unlike in, say, the United States, standardised company town architecture had communist ambitions. The concluding document of the same architectural conference stated: 'Architects must reflect in their creative work the deep changes in social development that have happened in the country of socialism.' As time went on, architects used increasingly sophisticated technology to combine welfare with industrial production. This was an especially acute concern in heavily polluting plants. In chemical enterprises during the Brezhnev era, for example, architects sought to design green squares with multiple functions, including a summer stage, a sports area and a zone for relaxation. The whole spatial organisation of the plant's outdoor welfare facilities was focused on reducing the threat from pollution. ${ }^{24}$ Nowhere were the architectural plans of company towns shot through so sharply and consistently by a welfare-inflected state ideology.

Nevertheless, the most important factor which marked out the Soviet company town from its capitalist counterparts was the scale and vision of its budgetary arrangements (which at times did 
little to ameliorate miserable squalor). Company towns shaped the entire Soviet welfare budget, or, to look at it differently, the welfare budget profoundly affected Soviet urban space.

Marked rises in investment followed Stalin's death. Flowing through a range of ministries and trade unions, financial allocations increased significantly in the early $1950 \mathrm{~s} .{ }^{25}$ The social insurance budget that was controlled by the railwayworkers' trade union was 400 million rubles higher in 1954 than it had been in 1951, while the healthcare budget of the Ministry of Communications (funding facilities for the same workers) increased by 227 million in the same period. New hospitals, polyclinics, and nurseries were constructed in urban areas, while some new rest houses and sanatoria were built in exurbia. It seems that the modification of the urban environment in major cities, such as Tbilisi, Alma-Ata and Cheliabinsk, was more significant than in small settlements. Inspectors praised the hospitals in those big cities, but castigated local officials in small settlements for failing to make full use of their welfare budgets. ${ }^{26}$

While the state budget, therefore, profoundly affected the design of the company town, it could not deliver on the plan. Soviet company towns varied dramatically in size, and those which were smallest were most vulnerable to the incapacity and inflexibility of economic planning. Many planners recognised that it was impossible to provide welfare services efficiently in very small settlements, an argument that gathered force during the Khrushchev era. ${ }^{27}$ As a result of underinvestment, planning failures, and geographical isolation, these small single-employer industrial settlements often became squalid places, scarcely the flagships of Soviet civilisation. We know little of their history from the inside, but we have evidence of violence and misery in small industrial settlements in Leningrad Region in the 1950s, with stories of murder and rape among migrant workers. ${ }^{28}$ These small-scale company towns remained rough-and-ready places, where the temporary and the permanent were held in tension, even in the 1970s. 'This was a bleak and untidy 
town, neither a city or a village,' wrote the village prose writer, Valentin Rasputin, in The Fire. 'It was more like a camp site, as if the residents, migrating from place to place, had stopped to wait out a storm and to rest up and had simply gotten stuck.' As a result, welfare was an eternal promise rather than a reality. 'And so the diagram in the town hall showed a recreation centre, but for twenty years now this recreation centre had been located in a public bath house brought here from one of the old workers' towns. They should have built a new one, but how could you build anything when nothing was visible up ahead until the very last minute?' Rasputin went on: 'There was also a nursery school on the diagram, but it was not in operation since nobody knew whether it was worth renovating. And it became clear that they were in no big hurry. Nobody held anybody responsible for these plans. ${ }^{29}$

But ideology did remain central to people's lives in single-employer towns, especially the larger ones. 'The activity of party, soviet, Komsomol and other public [obshchestvennye] organisations is connected, to the utmost degree, with production [proizvodstvennye] collectives, without which it would be impossible to imagine the social [obshchestvennye] life of small towns,' wrote an urban sociologist in 1972. He included the range of housing, education, welfare and leisure services, as well as the construction and regulation of urban space. ${ }^{30}$ For him, all these things -- some of the crucial components of Soviet civilisation as many citizens experienced them -- were derived from within the interstices of the company town. And so despite its imperfections, which were legion, the company town could formulate a mode of everyday life that was inflected by a sense of Soviet civilisation. Dniepropetrovsk was a five-star company town. Closed to foreigners, it was a metallurgical centre that became a focus of the space industry during the Brezhnev era. The Yuzhmash industrial combine built sports facilities, an airport, the opera house, the historical museum, a children's department store, as well as housing, libraries, cinemas and workers' clubs. ${ }^{31}$ This had some of the features of a 'total' urban environment. People's worldview was formed in 
such a space, which combined accessible theoretical nostrums -- the slogans about the world proletariat that were painted in massive murals on the side of factory buildings -- with a practical, everyday experience of what Soviet ideology meant in terms of psychological and material security. The anthropologist Alexei Yurchak points out (in a different context) that even relatively worldly and sceptical Soviet citizens could remain convinced of the virtues of such aspects of the ideological project even in the $1980 \mathrm{~s}^{32}$

At the heart of this ideological vision was a certain understanding of equality. One could even claim that the concept which was most Soviet about the company town was equality, which was manifested as a diurnal, dull reality. In a small railway settlement in a metropolitan hinterland, there was a bleakness about this equality, thanks to the relative paucity of welfare facilities. But equality, driven by welfare, could offer more in bigger company towns. It gave these places their most distinctive look. 'Magnitogorsk is a working-class city without unemployment or even the fear of being laid off, without a sizeable and visible underclass,' wrote Stephen Kotkin in a first-hand, Gorbachev-era account of the city. It was a city, he went on, 'without a conspicuous elite or wealthy class, or for that matter without any manifest personal wealth at all. ${ }^{33}$ This was mostly a post-Stalin phenomenon. The venality of local elites in provincial cities no doubt reinforced the misery of ordinary people in the immediate postwar period, ${ }^{34}$ but during the Khrushchev era, elites' arrogance became less acceptable, and ideological prescriptions concerning equality became ubiquitous. The neo-Leninist enthusiasm of the Khrushchev era generated an urban landscape in which equality was marked out in concrete, in the profusion of near-identical five-storey prefabricated apartment blocks. $^{35}$

Hierarchies were, however, more powerfully expressed in spatial form in Soviet cities in the 1970s and 1980s, perhaps especially in company towns. In a seminal work first published in 1982, 
the émigré scholar Victor Zaslavsky offered a number of explanations for this, including the tendency for better entrenched elites to reproduce their privileges. He also argued that the consolidation of the internal passport system in 1981 'maintain[ed] the hierarchy of locations, class and ethnic boundaries'. Combined with 'the institutionalisation of the restricted system of administrative distribution of goods and services', it ensured that some company towns were especially privileged locations. ${ }^{36}$ In elite company towns like those established by the nuclear industry, the scope and availability of welfare services, perhaps especially medical care, was noticeably better. ${ }^{37}$

But for most Soviet citizens, there seems little doubt that equality continued to shape urban space throughout the 1970s and 1980s in ways that forcefully struck foreign observers like the 1980s American student, Kotkin, and that was very different from the experience of the urban West. Equality was a hallmark. The company town survived the collapse of the USSR in 1991 and continues to exist today in parts of Russia, but it was the change to the strikingly unequal city that was the most distinctive transformation after 1991 in these places. ${ }^{38}$

\section{III}

\section{The rise and fall of the microdistrict}

In larger company towns and decent-sized Soviet cities of all types, the essential urban unit for the delivery of welfare was the new neighbourhood housing district, designated 'microdistrict' from the late $1950 \mathrm{~s} .{ }^{39}$ Microdistricts typically contained between five and twenty thousand residents, who lived in blocks of flats separated by yards. Architects aimed to provide playgrounds and green areas. Within a short walk were schools, kindergartens, and polyclinics -- or they should be, according to the plan. ${ }^{40}$ Other facilities, such as the 'social welfare offices' which urban residents had to visit in 
order to process welfare payments, were not located in every microdistrict. Moscow had twentyfive district welfare offices in 1956 (which were located at the raion level, roughly commensurate with a London borough) though inspectors operated within the microdistrict. ${ }^{41}$

Just as the company town was originally a capitalist form of settlement with a long history, the microdistrict had analogues abroad. By the 1950s and 1960s, it was a broadly universal modern aim to replace ill-served slums and shanty towns with mass-produced public urban housing supported by effective public services. At the fifth congress of the International Union of Architects, held in Moscow in 1958, the microdistrict was discussed in these internationally applicable, practical terms. Built from scratch, Brasília was divided into 'superquadros' of up to 2,500 residents, with access to appropriate social services. ${ }^{42}$ In the 1960 s, the Soviet microdistrict's function -- taking society to 'a new level' through the rationalised delivery of welfare services -was a carefully calibrated, explicitly modernising mission. ${ }^{43}$ But it was not only this.

During the Khrushchev era, this welfare agenda was overlaid with a powerful communist drive. Most importantly, the ideal of equality was not illusory. With the exception of the senior elites, all kinds of people lived in the microdistricts. The doctor and accountant brushed up against the factory worker and the cleaner. Meanwhile, in the late 1950s and early 1960s, the microdistrict was deliberately conceived as one of the primary sites of communist mobilisation. There is widespread evidence in citizens' letters to the authorities that people understood and even internalised this communist approach to life. For a spell in the late 1950 s and early 1960 s, it was the standard against which many people claimed to measure the welfare framework of their urban surroundings. ${ }^{44}$ Some communal or voluntarist imperatives were not unique to the Soviet Union, but they certainly took on a particular form in the communist-inspired microdistrict. At the height of the Khrushchev era, Moscow's Kuibyshev district housing administration committees number 26 
and 37 created children's and youth groups, which offered ideological instruction, workshops for learning skills, a supervised room for doing homework, and various other facilities. The groups were run by parental volunteers and paid professionals. Similar groups were found in Leningrad and Erevan, in other parts of Moscow, and no doubt elsewhere. ${ }^{45}$

Across the Soviet Union, the microdistrict was rolled out in cities with very different topographies, and in geographical zones with vastly different climates. Despite the considerable expense of constructing cities in the Arctic north, Stalinist planners designed them, and Khrushchev-era planners fitted them out with microdistricts. This achievement gave the Soviet welfare system one of its most distinctive spatial characteristics. It struck at the imagination of architects. In a fantastical variant of the microdistrict, a group of Leningrad architects drew up plans for community centres in Far Northern cities, which would be enclosed by domes and offer artificially mild microclimates. Urban residents would not live inside the dome, but they would relax in its green areas and enjoy access to the broad Soviet range of public facilities, such as a canteen, hairdresser, shops, social clubs, schools and kindergartens. ${ }^{46}$

The Khrushchev era was the high watermark of communist idealism and Leninist revivalism. During the years of Brezhnev, by contrast, the microdistrict was a venue not so much for the rehearsal of communist practices, as for the accumulation of welfare capacity. For sure, ideology made possible the extent and variety of welfare, and in that sense it continued to fashion a particularly 'communist' system of welfare in the microdistrict. But the communist dreaming had certainly gone. Correspondingly, technocracy became more significant. By the end of the 1960s, architects and planners were calculating precise levels of would-be provision inside microdistricts. One of the sharpest sources of contention was the availability of kindergarten spaces, notwithstanding a major expansion (a twofold rise in the 1960s alone) ${ }^{47}$ Investment was high, and 
planners promised much. The basic calculation was that for every one thousand inhabitants of a microdistrict, between seventy and ninety kindergarten places should exist. ${ }^{48}$ In such ways was the microdistrict -- the core unit of urban space -- supposed to shape social welfare, or, to reverse the analysis, did the calculation about necessary levels of welfare affect the design of the city.

Forceful political will, activated by a sporadic atmosphere of communist excitement, was the prerequisite of Khrushchev's major social reforms, such as the housing decree of 1957 and the pensions laws of 1956 and 1964. When that atmosphere dissipated from the early 1960s on, the political capacity to enact major social reforms was disabled. True, spending on welfare remained high, but the system as a whole was under pressure from the late 1970s and early 1980s. This had consequences inside the microdistrict, especially for pre-school childcare. Notwithstanding the planners' projections, data of 1969 suggested that kindergarten spaces existed for between only 21.1 per cent and 52.8 per cent of children. ${ }^{49}$ This was in some places sufficient. After all, there were demographic differences across the USSR: twice as many children were born in Turkmenistan compared with Latvia, for example. And many people preferred to take advantage of lengthy postnatal leave or live-in grandmothers. But other families failed to find the childcare that they needed, resorting to 'informal practices' and luck. In some places, under the pressure of kindergarten shortages alone, the ideal of the microdistrict faded fairly rapidly. In the seventies new town of Naberezhnye Chelny (renamed Brezhnev after the General Secretary's death), parents had to be prepared to travel quite long distances to drop off their child at kindergarten before continuing their journey to work, dissolving the principle of microdistrict provision. ${ }^{50}$

And so from the mid-1960s, the ideological character of the microdistrict became much less distinct. Lewis Siegelbaum charts the process whereby the microdistricts of Tol'iatti, a new city of the sixties designed to accommodate the construction of cars, started life in a spirit of 'modernity 
unbound', but quickly gave way to Soviet-style shortages and universal modern problems associated with high-rise estates and under-pressure welfare systems. He cites an 18,000 shortfall in kindergarten places in February 1976. ${ }^{51}$ Siegelbaum has therefore peeled back evidence of urban anomie in the provincial USSR in the 1970s which threatened fundamentally to distort the original communist aspirations of the microdistrict. As the 1980s started, architects and planners still used communist rhetoric, but in a formulaic way. ${ }^{52}$ True, some construction projects existed which were self-consciously derived from the original microdistrict, such as the 'housing complexes for young people' $(M Z h K i)$, collective-inspired blocks of flats equipped with public facilities, built in thirty Soviet cities between the mid-1970s and mid-1980s, and which aspired to promote 'new progressive forms of socialist living [obshchezhitiia] [... and] the all-sided development of the person, raising his or her voluntary activity [aktivnost']'. ${ }^{53}$ But these were a faint echo of Khrushchev-era idealism. Indeed, in an Arkhitektura SSSR discussion of autumn 1987 about what had become of the socialist city, which included the contributions of several architects, B. Neliubin wrote of the problems of 'drug addicts, drunkenness, social passivity', which he thought derived from the fact that 'our cities are primitively functional', and that they had lost their 'philosophical' and 'spiritual' life. ${ }^{54}$ In other words, the blunt forces of modernisation had lost the guidance of communist ideology.

The microdistrict also came under pressure because urban growth and changes in construction technology made it a less useful basic building block of the Soviet welfare system. Planners were falling back on less accessible or environmentally safe blocks of land, while apartment houses were becoming ever taller and bigger. One architectural commentator writing in 1982 stated that the microdistrict was 'losing its distinctness and precision [chetkost'] and socialplanning unity.' He cited the examples of microdistricts in Moscow, Kiev, Minsk, Tol'iatti and Naberezhnye Chelny, where several microdistricts were clustered on land between urban 
motorways [mezhmagistral'naia territoriia]. ${ }^{55}$ The vast size of some apartment blocks changed the character of yards. In the original conception of the microdistrict, yards were relatively enclosed (zamknutye) and not overcrowded, places in which people would have a sense that the space was communally theirs. Now, the pressure on land seemed to reduce people's ownership over their local welfare facilities, as the tightly planned clusters of welfare facilities were disrupted. ${ }^{56}$

Modernisation bred impersonality, which seemed uncongenial for socialist society (there was less talk of communism these days). By the 1980s, therefore, the ways in which the microdistrict shaped the Soviet welfare system had changed. As a spatial factor, it continued to give form to the delivery of welfare at a local urban level, and that form persisted into the post-Soviet period. But the content had changed.

\section{IV}

\section{The welfare office}

So much for the urban outdoors. What about the urban interior? To put the question differently: how was people's experience of welfare, and by extension their understanding of their citizenship, affected by the interior spaces in which welfare was dispensed? Welfare offices were the spatial manifestation of Soviet citizens' complex relationship to social insurance. They were the place people went to discuss their pensions: to request payment rises, to ask about unexpected payment falls, or to plead for special treatment. Pensions were not simply for the elderly, but were a catch-all term for various types of welfare benefit. There were pensions for living dependents, dependent survivors, the disabled, and the sick. After 1956, urban dwellers enjoyed comprehensive coverage; from 1964, a reduced version of the system was extended to those who worked in collective farms. But despite the system's extent, it faced ideological tensions. The relationship between equality and moral hazard was particularly difficult. ${ }^{57}$ In the workers' state, work was the cardinal virtue. The 
pensions system was partly predicated on the Leninist principle that crude obsessions with equality were 'petty bourgeois'. In other words, it was entirely right that people who had longer work records, or who had earned more because of their skills, or who had endured less desirable labour environments, should be better rewarded. It was precisely in the pensions office that this principle, more than any other, was debated and brought to life. Anxious or enraged, people came to these modest rooms to argue about the essence of Soviet socialism: about why it required them to have a better pension.

On July 14 1956, the party and government approved a decree on state pensions that was one of the most far reaching of Soviet welfare reforms. This measure expanded social provision into new sectors of the urban economy, clarified and streamlined the whole benefits system, and considerably increased the level of welfare payments. It only applied to urban dwellers. Social insurance spending per worker increased by sixty per cent as a result of the decree. When the decree was brought into force in October 1956, the number of new benefit claimants rose dramatically, while most existing claimants obtained higher payments. The day the decree became operational, tens of millions of people wanted to know exactly what benefit they could expect to receive and how to make sure they received it. In Moscow, as many as 1,500 people queued up at district welfare offices (ROSO) every day. ${ }^{58}$

This imposed extraordinary pressures on both physical space and staff. Many workers and old-age pensioners should have continued to discuss their welfare payments with their trade unions, in offices that were located within the precincts of the factory. But the welfare advisers in these institutions often found themselves badly briefed on the complex repercussions of the new regulations. People therefore flocked to the district offices. Even factory-based welfare professionals sometimes joined the queue at the city district offices (run by the city administration, 
or soviet) to try to seek out advice that they could pass on to their claimants, though they were heartily criticised for their incompetence. ${ }^{59}$

The result was a sequence of encounters, played out in a defined space, that significantly affected the popular understanding of welfare. It was the size and layout of the welfare office that partly defined people's status as welfare claimants, and therefore as Soviet citizens. Many district welfare offices throughout the RSFSR were located in basements (or 'semi-basements') and were often very cramped. In Moscow's Timiriazevskii district, the office was in a basement; ${ }^{60}$ in the capital's Sovetskii district, with responsibility for 36,000 claimants, the department was sited in a small semi-basement. Personnel pointed out that such locations offered little chance of talking calmly about complicated and sensitive matters. ${ }^{61}$ The furniture was often inadequate, sometimes with too few chairs for claimants to sit down. As a result, vulnerable people had to queue outside, in cold, rain or heat. ${ }^{62}$ It was not very convincing when the Minister of Social Welfare (RSFSR) claimed that, as a result of the 1956 law, many welfare departments had been outfitted, decorated, moved to new premises and equipped with new furniture, either on a temporary or a permanent basis. $^{63}$

Which was more significant: the direct impact of physical space on claimants, or the effect it had on the mood and working capacity of officials, which in turn caused problems for claimants, sometimes redefining their sense of citizenship? It was usually the officials, not the claimants, who were complaining about these conditions. No doubt it is only natural that officials flagged up a way of improving the welfare system that coincided with the construction of more comfortable offices for themselves. When pensioners of various types described the problems of the benefits system, they mentioned ill mannered staff more often than they mentioned cramped conditions. In late Stalinist Leningrad, where pensions offices were under acute pressure, dealing with the social 
insurance claims of the injured and bereaved, veterans especially would sometimes complain to the press about the conditions they experienced in these offices. It was precisely veterans who were experiencing an offended sense of entitlement, a diminution in their understanding of their citizenship. ${ }^{64}$ Most often, however, it seems that it was the rudeness of staff and their obsessive adherence to the letter of bureaucratic regulation that drove veterans to distraction. ${ }^{65}$

At moments of particular pressure, not just the postwar, but also, for example, following the introduction of the 1956 decree, the novelty of regulations, the sheer number of claimants, and the complexity of case files frayed the nerves of staff. Of course, the stress never really went away -after all, staff were scarcely seeing clients when they were at their most relaxed -- and they sometimes responded by shutting up shop at the first opportunity. Officials from the railway workers' trade union who were investigating pensions queues spotted a disabled man who had struggled to get to the welfare office in Moscow's Kirov district, and who arrived fifteen minutes late: he was 'driven back' (not home by complimentary taxi, but away from the office by the sharp words of the social welfare personnel). ${ }^{66}$ True, many officials were much more conscientious. But welfare officials exercised considerable power over individual cases, and they sometimes dispensed it with an ungenerous tone.

Does this mean that the relationship between official and claimant was asymmetric? Or, conversely, was it regulated by rights? In 1961, the welfare department in Moscow's Frunzenskii district was still located in a basement that lacked natural light. It consisted of four small rooms plus a ground-floor reception. It was a total of 238 square metres from which to serve 48,000 pensioners, and was not extended when the district was made bigger following a rezoning of city districts. Sixteen accounts workers found themselves two to a desk. ${ }^{67}$ But there is evidence of improvement. A report of 1968 urged managers at district level to make sure that welfare claimants were at the 
centre of their processes: the aim of officials should be to ensure that people had the chance to fulfil their rights; the physical condition of the reception room and the processes of receiving the public should reduce queues and foster 'cultured' conditions. ${ }^{68}$ In 1969, a pensions inspector in Moscow's Kalinin district praised the reorganisation of district borders that had changed the composition of his own district and also created a new Perovo district, because it made possible a much more efficient service for the local population. He claimed they had a motto: 'to serve the citizens of the district in a cultured, polite way, in order that not one comrade who has been in our departments should go away dissatisfied.' 69 In 1974, P. Mitrakov, a senior social welfare official in the Siberian city of Krasnoiarsk, called a department's reception 'a mirror of the work of the department'. If the reception dealt with a large numbers of the public -- 12,000 of them every year -- then it was the small details of the interior that should make possible 'a calm, business-like conversation' ${ }^{70}$ One might compare the places where people came to talk about pensions and housing. Sociological surveys of the 1960s and 1970s suggested that most people found the pensions office a more congenial environment than the local housing administration $(Z h E K) .{ }^{71}$ Housing issues were probably the most contested and anxiety-inducing everyday problems in all of Soviet life. Perhaps it was indeed the case that the welfare office became a lower-stress environment in the Khrushchev and Brezhnev eras thanks to its physical improvements, the greater professionalism of its staff, and the less asymmetric relationship between officials and the rights-bearing public.

As time went on, not only did the physical conditions in welfare offices improve, but so did the qualifications of the staff, which also became increasingly female. The Pervomaiskii district welfare department, which had won socialist competitions in 1970 and 1971, proclaiming it the best run in Moscow, dealt with 85,000 pensioners and benefits recipients, requiring 10,000 files to be prepared for further attention every year. Compared with the departments which had struggled so much in 1956, the Pervomaiskii department in 1971 contained more staff with more qualifications. 
Working in social security offices was responsible and stressful. Being a pensions official carried a similar status to that possessed by those who worked in other public-facing departments, such as the $Z h E K i$. But their salaries were relatively low. In the early 1980 s, teachers and factory workers could both expect to earn more. ${ }^{72}$ Nevertheless, welfare officials enjoyed the prestige associated with responsibility, education, and, even in the workers' state, the comfort of working in a clean whitecollar environment. Their relationship with claimants was quite different from that of the counterparts in capitalist countries. By the 1980s, welfare bureaucrats in Britain were moving from a language of the 'client' towards one of the 'consumer', in an attempt more closely to invest claimants with rights and citizenship. But their accounts of how this works in practice remind the Soviet historian that they were dealing with poorer and weaker social groups. ${ }^{73}$ In the United States, the history of welfare bureaucracy and the regulation of the poor might be synonymous. ${ }^{74}$

But the Soviet welfare system was entirely different. It was for everyone, all of the time. The welfare office might have had a faded décor by the late socialist period. It might have lost the bright red promise of the Khrushchev years. But it was still a fundamentally different place to its comparators in capitalist countries. The Soviet welfare office was not just a place of bitter confrontation, the site of individuals' post-catastrophes, as it was in Weimar Berlin, for example. ${ }^{75}$ It was the spatial embodiment of a grander goal. The Soviet welfare system was much more concerned with the regulation of society as a whole than just the regulation of the poor. As such, the urban welfare system reached not just into the pensions office, but also went beyond the city limits. 
It seemed that the boundaries of the Soviet city were precisely defined: that a line separated what was urban from what was rural. In administrative terms, a town and its surrounding region were separate categories; in Tiraspol in the 1960s and 1970s, the executive committees that governed the city and region were in the same building, but had little to do with each other. ${ }^{76}$ And according to urban planners, the city was an entity with clearly drawn edges. Nowhere was this truer than in Moscow, whose borders coincided with the outer ring road. ${ }^{77}$ Spatial boundaries were mirrored by legal ones. Residency laws were hierarchical, predicated on the assumption, first, that living in a city bestowed more rights than living in a village and, second, that some cities were more privileged than others. Socialism was in the first instance an urban project and the Soviet Union was, after all, the industrial workers' state.

Being an urbanite carried a specific status and offered access to particular types of welfare. ${ }^{78}$ A stamp in the internal passport granted a citizen the right to live in a particular place, and the place could not easily be upgraded. This very stamp mediated access to a pension. Collective farm workers were not part of the wider state welfare system until 1964. When people moved to cities without seeking formal permission -- an isolated parent, say, coming to live in a son's overcrowded Kiev flat -- they would automatically lose access to all social security provision. Social security professionals were aware of the problem and sometimes bent the rules to help such people out. ${ }^{79}$ But the law was clear. Social rights in the USSR were contingent on location. This did not make the Soviet Union unique -- one only has to look to the blend of federal and state entitlements in the United States, or the complex geographical range of rights-based benefits in India, for example -but it was a fundamental fact of Soviet life.

A legal history of Soviet welfare would therefore emphasise the significance of the city limits. By contrast, a spatial history would stress the fuzziness of the urban boundary. This is a 
paradox, given the importance that urban planners placed on the city as a discrete unit. But in the use of physical space for the purposes of welfare, city and non-city were not quite distinct.

Khrushchev considered this relative fuzziness a policy position. In 1949, he had recklessly announced his support for the principle of the 'agro-town'. The idea was that rural settlements should have more urban trappings, and that the gap in standard of living between city and countryside should narrow. Accused of speaking out of turn, he had to admit that this was a mistake. But it seemed to be his view, and he was anyway giving voice to an older model of Soviet urbanisation, according to which towns should grow and export their qualities to their rural surroundings, without simply creating badly served urban outskirts. ${ }^{80}$ In the 1950 s and 1960 s, Khrushchev returned to an attenuated version of the principle of mixed rural-urban forms of settlement, in which, he hoped, large villages would come to many of the social and infrastructural advantages of towns. Welfare services, broadly conceived, were at the heart of this vision. It drew on a minor tradition in Soviet town planning, such as the 'disurbanist' thinking of the $1920 \mathrm{~s},{ }^{81}$ and also fitted within both the Stalinist and post-Stalinist variants of post-war reconstruction and urbanisation..$^{82}$

However urban it might have seemed, the company town was never far from rural life. Even in a vast complex of gigantic furnaces and endless pipes, much of the workforce had recently migrated from the village. In the postwar years, many factories effectively ran their own farms, without which they would have been unable to feed their workers. The deputy chairman of the Architecture Committee of the Council of Ministers (USSR), B.P. Rubanenko, pointed out at an inter-departmental conference in March 1948 that many towns -- he mentioned Nizhnii Tagil and Kemerovo, among others -- effectively contained around twenty or thirty backward settlements (poselki). This was 'a disreputable practice', he claimed. ${ }^{83}$ The fear was that normal urban 
conditions were compromised, and that the systematic provision of decent housing -- Rubanenko's primary concern -- would be impossible.

After the end of the postwar emergency, welfare generated a different relationship between town and country. Rather than the exurban infecting the integrity of the city's welfare provision, the city made use of the welfare potential of the countryside on a much more systematic scale than hitherto. The welfare resources of company towns extended to sanatoria and rest houses, places where workers could go for health-focused holidays or periods of recuperation and recovery from illness and injury. ${ }^{84}$ Ordinary people had increasing opportunities to build or purchase dachas: ${ }^{85}$ a process which might be perceived as a benign collision of property law and social policy. Some institutions organised countryside or seaside facilities for employees' children (though most Pioneer camps were owned and managed by the hierarchy of the Komsomol).

Pioneer camps were a central example of the city making use of the countryside -- in a sense, colonising it -- for welfare purposes. When Viacheslav Molotov visited the showcase Artek Pioneer camp, spectacularly located on the Crimea, in August 1955, the director proudly told him: 'In Moscow there is not even a proper Pioneer palace. ${ }^{96}$ Within three years, work would start on precisely such a facility, in Moscow's Lenin Hills; the Moscow Pioneer Palace was finished in 1962. ${ }^{87}$ But the Artek director's point was telling. Moscow needed exurbia in its multiple guises in order to provide welfare.

When the village prose writer Vladimir Soloukhin spent the summer of 1956 walking around his native countryside, a hundred miles or so from Moscow but seeming much further away, he was also, incidentally, walking across a landscape of exurban welfare. He wanted to get off the beaten track, but he saw Pioneer camps, rest houses and old people's homes. These were rural 
outposts of the giant Soviet welfare system. They provided summer childcare and ideological instruction, health-focused holidays dispensed by trade unions, and state-run accommodation and care for relatively small numbers of elderly people. Some of this was for rural inhabitants. But much of it was for urbanites..$^{88}$

The Soviet welfare system shaped Soviet cities; Soviet cities shaped the Soviet welfare system. Other factors contributed to the design and experience of urban form and welfare alike. But this symbiotic relationship between city and welfare was a crucial aspect of Soviet history. Generalising about the 'socialist city', the 'Nazi city' and the 'capitalist city' is reductive and ultimately counterproductive. But it is surely true that the Soviet city, like the socialist city more generally, was defined to a considerable extent by the welfare that was dispensed within it. The capitalist and Nazi city, by contrast, were most obviously defined, respectively, by private property relations and the politics of violent racial exclusion. Recovering some of the particular places in which Soviet urban welfare was experienced -- the company town, the microdistrict, the welfare office, and exurbia -- thus takes us closer to the distinctiveness of the post-1953 Soviet city. True, it lost the most striking ambition of the Khrushchev years, and became only a faded version of paradise, marked by imperfections and incapacities, and partly shaped by universal modernising forces. But the spatial expression of ideology ultimately made the Soviet city the flagship of a highly particular civilisation. 
${ }^{1}$ The research for this article was funded by the Arts and Humanities Research Council of the United Kingdom.

${ }^{2}$ For a memorable description, see Malcolm Bradbury's novel, Rates of Exchange (London: Secker and Warburg, 1983).

${ }^{3}$ E.g. R. A. French and F. E. Ian Hamilton (eds), The Socialist City: Spatial Structure and Urban Policy (Chichester: Wiley, 1979).

${ }^{4}$ E.g. Heather D. DeHaan, Stalinist City Planning: Professionals, Performance, and Power (Toronto: University of Toronto Press, 2013).

${ }^{5}$ Leif Jerram, Streetlife: The Untold History of Europe's Twentieth Century (Oxford: Oxford University Press, 2011).

${ }^{6}$ William Jay Risch, The Ukrainian West: Culture and the Fate of Empire in Soviet Lviv (Cambridge, MA: Harvard University Press, 2011).

${ }^{7}$ Lewis H. Siegelbaum, Cars for Comrades: The Life of the Soviet Automobile (Ithaca, NY: Cornell University Press, 2008).

${ }^{8}$ E.g. Catriona Kelly, St Petersburg: Shadows of the Past (New Haven, CT: Yale University Press, 2014).

${ }^{9}$ Even when citizens were themselves contributing to the rebuilding of the urban welfare infrastructure after the Second World War, their voluntarism fitted into a socialist framework. For the example of urban Crimea, see M. M. Maksimenko, Mestnye sovety Kryma v poslevoennyi period, 1945-1958 (Kiev: Naukova dumka, 1972), 89.

${ }^{10}$ Elidor Mëhilli, 'The socialist design: urban dilemmas in postwar Europe and the Soviet Union', Kritika: Explorations in Russian and Eurasian History, 13:3 (summer 2012): 635-65 (658-61).

${ }^{11}$ On social rights, see Mark B. Smith, 'Social rights in the Soviet dictatorship: the constitutional right to welfare from Stalin to Brezhnev', Humanity 3:3 (2012): 385-406.

${ }^{12}$ Peter Baldwin, The Politics of Social Solidarity: Class Bases of the European Welfare State 1875-1975 (Cambridge: Cambridge University Press, 1990), 146.

${ }^{13}$ Stephen Kotkin, Magnetic Mountain: Stalinism as a Civilization (Berkeley, CA: University of California Press, 1995).

${ }^{14}$ Karl Schlögel, Moscow 1937 (Cambridge: Polity, 2012).

${ }^{15}$ Notably Mark Bassin, Christopher Ely and Melissa K. Stockdale, Space, Place and Power in Modern Russia: Essays in the New Spatial History (DeKalb, IL: Northern Illinois University Press, 2010).

${ }^{16}$ Lewis H. Siegelbaum and Leslie Page Moloch, Broad is My Native Land: Repertoires and Regimes of Migration in Russia's Twentieth Century (Ithaca, NY: Cornell University Press, 2014).

${ }^{17}$ Stephen V. Bittner, The Many Lives of Khrushchev's Thaw: Experience and Memory in Moscow's Arbat (Ithaca, NY: Cornell University Press, 2008); Christopher J. Ward, Brezhnev's Folly: The Building of BAM and Late Soviet Socialism (Pittsburgh, PA: University of Pittsburgh Press, 2009); Brian LaPierre, Hooligans in Khrushchev's Russia: Defining, Policing, and Producing Deviance during the Thaw (Madison, WI: University of Wisconsin Press, 2012).

${ }^{18}$ E.g. James H. Bater, The Soviet City: Ideal and Reality (London: Edward Arnold, 1980).

${ }^{19}$ Greg Castillo, 'Stalinist Modern: Constructivism and the Soviet Company Town' in James Cracraft and Dan Rowland, eds., Architectures of Russian Identity, 1500 to the Present (Ithaca, NY: Cornell University Press, 2003), 131-149.

${ }^{20}$ Simon Clarke, The Development of Capitalism in Russia (London: Routledge, 2007), 42-4.

${ }^{21}$ It bore striking similarities to 'company towns' in other parts of the Eastern bloc, at least in design and planning. Nowa Huta is only the most famous example: Katherine Lebow, Unfinished Utopia: Nowa Huta, Stalinism, and Polish Society, 1949-1956 (Ithaca, NY: Cornell University Press, 2013).

${ }^{22}$ Alan Barenberg, Gulag Town, Company Town: Forced Labor and its Legacy in Vorkuta (New Haven, CT: Yale University Press, 2014). 
${ }^{23}$ Iu. L. Kosenkova, Sovetskii gorod: 1940-x -- pervoi poloviny 1950-x godov: Ot tvorcheskikh poiskov k praktike stroitel'stva (Moscow: URSS, 2000), 278: 'From the decree of a creative congress of architects from Moscow, Leningrad, Khar'kov, Sverdlovsk and Dnepropetrovsk working in industrial architecture, 20 December 1952'.

${ }^{24}$ N. Abesinova, 'Blagoustroistvo territorii khimicheskikh predpriiatii', Arkhitektura SSSR 1969: 7: 22.

25 This process continued and expanded between the 1960s and 1980s: A.S. Seniavskii, Rossiiskii gorod 1960-e -- 80-e gody (Moscow: RAN IRI, 1995), 203.

${ }^{26}$ Gosudarstvennyi Arkhiv Rossiiskoi Federatsii (State Archive of the Russian Federation, hereafter GARF) f. R-5451, op. 25, d. 5339, 1. 39 (Railwayworkers trade union report of 1954).

${ }^{27}$ V. G. Davidovich, Rasselenie v promyshlennykh uzlakh: inzhernerno-ekonomicheskie osnovy (Moscow: Gosizdat literatury po stroitel'stvu, arkhitekture i stroitel'nym materialam), 1960, ch.10. Larger cities were also relatively inefficient according to this argument.

${ }^{28}$ Dan Healey, 'Comrades, queers and "oddballs": sodomy, masculinity and gendered violence in Leningrad Province of the 1950s', Journal of the History of Sexuality 21:3 (September 2012): 496-522.

${ }^{29}$ Valentin Rasputin, The Fire, in Siberia on Fire: Stories and Essays (selected, translated and with an introduction by Gerald Mikkelson and Margaret Winchell, DeKalb, IL: Northern Illinois University Press, 1989), $109,111$.

${ }^{30}$ B. S. Khorev (ed.), Malyi gorod: sotsial'no-demograficheskoe issledovanie nebol'shogo goroda (Moscow: Iz-vo Moskovskogo universiteta, 1972), 128 (section authored by V.A. Sysenko).

${ }^{31}$ Sergei Zhuk, Rock and Roll in the Rocket City: The West, Identity, and Ideology in Soviet Dniepropetrovsk ) (Washington, DC: Woodrow Wilson Center Press, 2010, 22.

${ }^{32}$ Alexei Yurchak, Everything Was Forever Until It Was No More: The Last Soviet Generation (Princeton, NJ: Princeton University Press, 2005).

${ }^{33}$ Stephen Kotkin, Steeltown, USSR: Soviet Society in the Gorbachev Era (Berkeley, CA: University of California Press, 1991), xiv.

${ }^{34}$ Cynthia Hooper, 'A darker "big deal”: concealing party corruption, 1945-53', in Juliane Fürst (ed.), Late Stalinist Russia: Society between Reconstruction and Reinvention (London: Routledge, 2006).

${ }^{35}$ Mark B. Smith, Property of Communists: The Urban Housing Program from Stalin to Khrushchev (DeKalb, IL, 2010), ch. 3.

36 Victor Zaslavsky, The Neo-Stalinist State: Class, Ethnicity, and Consensus in Soviet Society (Armonk, NY: M.E. Sharpe, 1994), 78

${ }^{37}$ Kate Brown, Pluotpia: Nuclear Families, Atomic Cities, and the Great Soviet and American Plutonium Disasters (Oxford: Oxford University Press, 2013), ch. 34.

${ }^{38}$ On 'just reward' and dignity, which bore a complex relationship to equality in the USSR and which are now entirely detached from each other in post-Soviet Russia, see Jeremy Morris, 'Low wages and no dignity: Russian workers reflect on the stark post-Soviet choices in blue-collar employment', International Labor and Working-Class History 84 (2013): 271-77.

39 Their fame stretched to fiction: Lazar' Karelin, Mikroraion, published in Iunost',1962: 6: 2-34; 7: 38-64.

${ }^{40}$ Mark B. Smith, Property of Communists: The Urban Housing Program from Stalin to Khrushchev (DeKalb, IL: Northern Illinois University Press, 2010), 116-21.

41 GARF f. 5451, op. 29, d. 723, 1. 79 (stenogram of pensions conference of 19 November 1956).

42 James C. Scott, Seeing Like a State: How Certain Schemes to Improve the Human Condition Have Failed (New Haven, CT: Yale University Press, 1998), 125.

${ }^{43}$ O. Ignatov, N. Kolomiets, 'Na novom etape', Sovetskaia arkhitektura 17 (1965): 23.

${ }^{44}$ Smith, Property of Communists, 127.

${ }^{45}$ Rossiiskii Arkhiv Sotsial'noi i Politicheskoi Istorii (Russian State Archive of Social and Political History, hereafter RGASPI) f. 8, op. 1, d. 149, 1. 12. 
${ }^{46}$ S. Odnovalov, M. Tsimbal, 'Dlia krainego severa’, Sovetskaia arkhitektura 17 (1965): 57

${ }^{47}$ Catriona Kelly, Children's World: Growing up in Russia, 1890-1991 (New Haven, CT: Yale University Press, 2007), 409.

${ }^{48}$ N. Blokhina, 'Detskie uchrezhdeniia goroda', Arkhitektura SSSR, 1969: 8: 24.

${ }^{49}$ Ibid.

${ }^{50}$ Esther Meier, 'On the streets of a truck-building city: Naberezhnye Chelny in the Brezhnev era' in Lewis H. Siegelbaum, ed., The Socialist Car: Automobility in the Eastern Bloc (Ithaca, NY and London: Cornell University Press, 2011), 105-23: 115-8.

${ }^{51}$ Lewis H. Siegelbaum, 'Modernity unbound: the new Soviet city of the sixties' in Anne E. Gorsuch and Diane P. Koenker, eds., The Socialist Sixties: Crossing Borders in the Second World (Bloomington, IN: Indiana University Press, 2013), 75 .

52 E.g. 'Radi blaga sovetskogo naroda’ [editorial], Arkhitektura SSSR 1981: 2: 1.

${ }^{53}$ N. Ovsiannikova, 'Molodezhnye zhilye kompleksy', Arkhitektura SSSR 1984: November-December: 63-5.

${ }^{54}$ Feature on 'Sotsialisticheskii gorod. Kakim emu byt', Arkhitektura SSSR 1987: September-October: 30-7.

${ }^{55}$ A. Volkov, 'Ostanetsia li mikroraion zavtra?', Arkhitektura SSSR, 1982: 1: 25-6.

${ }^{56}$ Derived from V. Sokolov, 'Zhiloi raion Krylatskoe. Gradostroitel'nyi eksperiment', Arkhitektura SSSR, 1986: MarchApril: 38-9.

${ }^{57}$ Mark B. Smith, 'The withering away of the danger society: the pensions reforms of 1956 and 1964 in the Soviet Union', Social Science History 39:1 (2015, forthcoming).

${ }^{58}$ GARF f. 5451, op. 29, d. 723, 1. 12.

${ }^{59}$ By, e.g., the Minister of Social Welfare (RSFSR): GARF f. 5451, op. 29, d. 723, 1. 9.

${ }^{60}$ GARF f. 5451, op. 29, d. 723, 1. 77: Comrade Lukina, deputy head of zavkom of factory no. 2402, Moscow.

${ }^{61}$ GARF f. 5451, op. 29, d. 723, 1. 82: Comrade Goloborod'ko, head of pensions sector of Moscow city department of social welfare.

${ }^{62}$ GARF f. 5451, op. 29, d. 723, 1. 9: comrade Murav’eva, Minister of Social Welfare (RSFSR).

${ }^{63}$ GARF f. 5451, op. 29, d. 723, 1. 5.

${ }^{64}$ Mark Edele, Soviet Veterans of the Second World War: A Popular Movement in an Authoritarian Society, 1941-1991 (Oxford: Oxford University Press, 2008), ch. 8.

${ }^{65}$ Robert Dale, 'Re-adjusting to Life After War: The Demobilization of Red Army Veterans in Leningrad and the Leningrad Region, 1944-50', PhD thesis, Queen Mary, University of London, 2010, 161.

${ }^{66}$ GARF f. 5451, op. 29, d. 723, 1. 69: Comrade Pavliuchenko, deputy head of social insurance, railway workers' trade union.

${ }^{67}$ Tsentral'nyi Arkhiv Goroda Moskvy (Central Archive of the City of Moscow, hereafter TsAGM) f. 1937, op. 1, d. 147, 1. 8: report on conditions and the state of work in district departments of social welfare in the first half of 1961.

${ }^{68}$ TsAGM f. 1937, op. 1, d. 298, 1. 17: report on the conclusion of the organs of social welfare in Moscow for 1968 and the tasks for the further improvement of service for the population'.

${ }^{69}$ TsAGM f. 1937, op. 1, d. 298, 1. 41: stenogram of meeting of aktiv of employees of organs of social welfare in Moscow, 13 February 1969 (speech by Comrade Ostromenskaia, inspector at Kalinin ROSO.

${ }^{70}$ P. Mitrakov, 'Priem -- zerkalo raboty otdela', Sotsial'noe obespechenie 1974: 2: 10-12

${ }^{71}$ Zvi Gitelman, 'Unequal encounters: the citizen and the Soviet welfare bureaucracies' in Gail W. Lapidus and Guy E. Swanson (eds), State and Welfare USA / USSR: Contemporary Policy and Practice (Berkeley, CA: Institute of International Studies, University of California, Berkeley, 1988), 320-51 (332-2). 
72 Ol'ga V. Kapustina, 'Deiatel'nost' sovetskogo gosudarstva po sovershenstvovaniiu pensionnogo obespecheniia grazhdan (vtoraia polovina 1950-kh - 1980-e gody', Candidate of Sciences [PhD] dissertation, Leningrad State University, 2010, 133.

${ }^{73}$ See, e.g., the collection of essays in Drew Clode, Christopher Parker and Stuart Etherington (eds), Towards the Sensitive Bureaucracy: Consumers, Welfare and the New Pluralism (Aldershot: Gower), 1987.

${ }^{74}$ David Brian Robertson, 'Historical institutionalism, political development, and the study of American bureaucracy' in Robert F. Durant (ed.), The Oxford Handbook of American Bureaucracy (Oxford: Oxford University Press, 2010), 25-51 (29).

${ }^{75}$ Moritz Föllmer, Individuality and Modernity in Berlin: Self and Society from Weimar to the Wall (Cambridge: Cambridge University Press, 2013), 82.

${ }^{76}$ Ronald J. Hill, Soviet Political Elites: The case of Tiraspol (London: Martin Robertson, 1977, 142.

${ }^{77}$ Construction on the ring road started in 1956. Timothy J. Colton, Moscow: Governing the Socialist Metropolis (Cambridge, MA: Belknap Press of Harvard University Press, 1995), 373.

${ }^{78}$ For an overview of the difference between urban and rural status as it related to welfare, see Mervyn Matthews, Class and Society in Soviet Russia (London: Allen Lane, 1972), ch. 3.

${ }^{79}$ Smith, 'Withering away of the danger society'.

${ }^{80}$ Kosenkova, Sovetskii gorod, 151-8.

${ }^{81}$ S. Frederick Starr, 'Visionary town planning during the Cultural Revolution' in Sheila Fitzpatrick (ed.), Cultural Revolution in Russia, 1929-1931 (Bloomington, IN: Indiana University Press, 1978), 207-40.

${ }^{82}$ For the complexity of urban-rural relations and differences, see Mark Edele, 'Veterans and the village: the impact of Red Army demobilization on Soviet urbanization, 1945-1955', Russian History 36:2 (2009): 159-82.

${ }^{83}$ Kosenkova, Sovetskii gorod, 270.

${ }^{84}$ As they had done before 1941, but from the 1950s they did so on a new scale. Diane Koenker, Club Red: Vacation Travel and the Soviet Dream (Ithaca, NY: Cornell University Press, 2013(.

${ }^{85}$ Stephen Lovell, Summerfolk: A History of the Dacha, 1710-2000 (Ithaca, NY: Cornell University Press, 2003).

${ }^{86}$ RGASPI f. 8, op. 1, d. 131, 1. 20: protocol of meeting of Artek administration, 23 August 1955.

87 Susan E. Reid, 'Khrushchev in Wonderland: the Pioneer Palace in Moscow's Lenin Hills', Carl Beck Papers in Russian and East European Studies, 2002.

${ }^{88}$ Vladimir Soloukhin, A Walk in Rural Russia (trans. Stella Miskin; London: Hodder and Stoughton, 1966), 26-7, 29, 69,114 . 